Rev. Fac. Agron. (LUZ). 2021, 38: 128-150. Enero-Marzo.

DOI: https://doi.org/10.47280/RevFacAgron(LUZ).v38.n1.07

ISSN 2477-9407

\title{
Sensory atributes, nutricional values and innocuousness of hamburgers made with cherry pulp, soy and pork meet
}

\begin{abstract}
Atributos sensoriales, valor nutricional e inocuidad de hamburguesas elaboradas con pulpa de cereza, soya y carne de cerdo
\end{abstract}

\begin{abstract}
Atributos sensoriais, valor nutricional e segurança de hambúrgueres feitos com polpa de cereja, soja e carne de porco
\end{abstract}

\section{Nelson E. Loyola Lopez*, Carlos Acuña Carrasco and Mariela A. Arriola Herrera}

\begin{abstract}
Department of Agricultural Sciences. Faculty of Agricultural Sciences and Forestry. Maule Catholic University, 684, Carmen, Curicó, Chile. E-mail: (NL) nloyola@ucm.cl, (D; (CA) cacunac@gmail.com, (D); (MA) marriola@ucm. $\mathrm{cl}$, (D).
\end{abstract}

\section{Abstract}

The addition of pulps and extracts from some fruits has proved to be good to replace fat in food, aside from the addition oCof a higher nutritional value to chopped-meat products, such as hamburgers. In this work, hamburgers made with pork meet with the addition of cherry pulp and soy protein were assessed; physical, chemical and microbiological aspects were analyzed as well as their sensorial qualities. Three treatments with different percentages such as; pork meet $63.4 \%$, cherry pulp $8 \%$, soy protein $4.3 \%$ and biosalt $1.1 \%$ were made. Moisture was determined by the method (AOAC 950.46). In addition, $\mathrm{pH}$ and the percentage of lactic acid present in hamburgers was measured, presence of $E$. coli, as well as the sensorial evaluation according to their sensorial attributes and their overall acceptability. The content of moisture was not significantly different among the treatments $(\mathrm{p} \leq 0.05)$. Percentage of fat changed 30.5 $\%\left(\mathrm{~T}_{1}\right)$ and $34.4 \%\left(\mathrm{~T}_{3}\right)$, being observed significant differences between both

Recibido el 01-11-2020 • Aceptado el 24-06-2020.

*Autor de correspondencia. Correo electrónico: nelsonloyola@hotmail.com 
Rev. Fac. Agron. (LUZ). 2021, 38: 128-150. Enero-Marzo.

Loyola et al.

treatments $(\mathrm{p} \leq 0.05)$. The $\mathrm{pH}$ varied between $32 \%\left(\mathrm{~T}_{1}\right), 5.5 \%\left(\mathrm{~T}_{2}\right)$ and $23.7 \%$ $\left(\mathrm{T}_{3}\right)$ as compared with the hamburgers made in the control treatment $\mathrm{T}_{0}$, being significantly different from those made in treatments $\mathrm{T}_{1}$ and $\mathrm{T}_{2}$. The content of lactic acid showed an increase of $71.4 \%\left(\mathrm{~T}_{1}\right), 69.2 \%\left(\mathrm{~T}_{2}\right)$ and $36.4 \%\left(\mathrm{~T}_{3}\right)$, being significantly different among them. Significant differences $(p \leq 0.05)$ in the perception of the attributes color and texture on the assessed hamburgers were detected, which did not happen with the attributes flavor and aroma. The microbiological evaluation, it was observed no presence of E.coli. The hypothesis of this study was not completely fulfilled because the addition of cherry pulp to make hamburgers effectively reduced the fat content, but the sensorial chemical aspects, acceptability and innocuousness did not show any improvement as compared to the control treatment.

Key words: fatty acid, soy protein, cherry pulp, pork meet.

\section{Resumen}

Se ha demostrado que la adición de pulpas y extractos de algunas frutas es buena para reemplazar las grasas en los alimentos, aparte de la adición de un mayor valor nutricional a los productos de carne picada, como las hamburguesas. En este trabajo se elaboraron hamburguesas de carne de cerdo, con la adición de pulpa de cerezas, proteína de soya y se analizaron los atributos físicos, químicos, microbiológicos y su calidad sensorial. Se formularon tres tratamientos con diferentes porcentajes de carne de cerdo $63.4 \%$, pulpa de cereza $8 \%$, proteina de soya $4.3 \%$ y biosal $1.1 \%$ de pulpa de cereza. Se determinó la humedad con el método (AOAC 950.46). Se midió $\mathrm{pH}$ y el porcentaje de ácido láctico presente en las hamburguesas. Se evaluó la presencia de $E$. coli mediante el método recuento en placa y la evaluación sensorial de las hamburguesas elaboradas, según sus atributos sensoriales y aceptabilidad general. El contenido de humedad no presentó diferencias significativas entre los diferentes tratamientos $(p \leq 0,05)$. El porcentaje de grasa varió un 30,5\% $\left(\mathrm{T}_{1}\right)$ y $34,4 \%\left(\mathrm{~T}_{3}\right)$ siendo detectadas diferencias significativas en ambos tratamientos $(\mathrm{p} \leq 0,05)$. El $\mathrm{pH}$ varió entre un $32 \%\left(\mathrm{~T}_{1}\right) 25,5 \%\left(\mathrm{~T}_{2}\right)$ y un $23,7 \%\left(\mathrm{~T}_{3}\right)$ respecto a las hamburguesas elaboradas con el tratamiento $\mathrm{T}_{0}$, siendo significativamente diferentes con el tratamiento $\mathrm{T}_{1} \mathrm{y} \mathrm{T}_{2}$. El contenido de ácido láctico aumento a 71,4\% $\left(\mathrm{T}_{1}\right) ; 69,2 \%\left(\mathrm{~T}_{2}\right)$ y $36,4 \%$ $\left(\mathrm{T}_{3}\right)$, siendo significativamente diferente. Se detectaron diferencias significativas $(p \leq 0,05)$ en la percepción de los atributos color y textura en las hamburguesas evaluadas, lo que no ocurrió con los atributos sabor y aroma. Respecto de la evaluación microbiológica, no se observó presencia de $E$. coli. La hipótesis del presente estudio no fue completamente aceptada, debido a que la adición de pulpa de cereza en las hamburguesas elaboradas, redujo el contenido de grasa, sin embargo, tanto los parámetros químicos, como sensoriales de aceptabilidad e inocuidad no mostraron una mejora en comparación con el tratamiento testigo. Palabras clave: ácidos grasos, proteína de soya, pulpa de cereza, carne de cerdo. 
Rev. Fac. Agron. (LUZ). 2021, 38: 128-150. Enero-Marzo.

Loyola et al.

\section{Resumo}

A adição de polpas e extratos de algumas frutas mostrou-se boa para substituir as gorduras nos alimentos, além de agregar um maior valor nutricional aos produtos de carne picada, como hambúrgueres. Neste trabalho, foram confeccionados hambúrgueres suínos, com adição de polpa de cereja, proteína de soja e os atributos físicos, químicos, microbiológicos e sua qualidade sensorial. Três tratamentos foram formulados com diferentes porcentagens de $63,4 \%$ de porco, polpa de cereja $8 \%$, proteína de soja $4,3 \%$ e polpa de cereja biosal 1,1\%. A umidade foi determinada com o método (AOAC 950.46). Foram medidos o $\mathrm{pH}$ e a porcentagem de ácido lático presente nos hambúrgueres. A presença de E. coli foi avaliada pelo método da contagem de placas e pela avaliação sensorial dos hambúrgueres, de acordo com seus atributos sensoriais e aceitabilidade geral. $\mathrm{O}$ teor de umidade não apresentou diferenças significativas entre os diferentes tratamentos $(\mathrm{p} \leq 0,05)$. O percentual de gordura variou de $30,5 \%$ (T1) e $34,4 \%$ (T3), sendo detectadas diferenças significativas nos dois tratamentos $(\mathrm{p} \leq 0,05)$. O pH variou entre 32 \% (T1) 25,5 \% (T2) e 23,7 \% (T3) em relação aos hambúrgueres feitos com o tratamento T0, sendo significativamente diferente nos tratamentos T1 e T2. O teor de ácido láctico aumentou para 71,4\% (T1); 69,2\% (T2) e 36,4 $\%$ (T3), sendo significativamente diferentes. Diferenças significativas $(p \leq 0,05)$ foram detectadas na percepção dos atributos de cor e textura nos hambúrgueres avaliados, o que não ocorreu com os atributos sabor e aroma. Em relação à avaliação microbiológica, não foi observada presença de $E$. coli. A hipótese do presente estudo não foi totalmente aceita, uma vez que a adição de polpa de cereja aos hambúrgueres processados reduziu o teor de gordura, no entanto, tanto os parâmetros químicos quanto os sensoriais de aceitabilidade e segurança não apresentaram melhora na comparação com o tratamento controle.

Palavras-chave: ácidos graxos, proteína de soja, polpa de cereja, carne de porco.

\section{Introduction}

In the last decade, the number of diseases associated with food with high contents of fat has dramatically increased, which has caused a change in consumers' mentality, who seek for a healthier life; this has caused the need to supply a diet rich in saturated fats to achieve a healthier one (Carrapiso, 2007). Furthermore, it should be added that the pace of life of the world's population today makes evident the

\section{Introducción}

En la decada pasada, el número de enfermedades asociadas con alimentos con altos contenidos de grasa se incrementó dramáticamente, lo cual ha causado un cambio en la mentalidad de los consumidores, para intentar una vida saludable; esto ha creado la necesidad de sustituir las dietas ricas en grasas saturadas para lograr una más saludable (Carrapiso, 2007). Por otro lado, cabe añadirse que el ritmo 
Rev. Fac. Agron. (LUZ). 2021, 38: 128-150. Enero-Marzo.

Loyola et al.

necessity of the consumption of fast food with a high energy value and with the time of preparation as an increasing additional factor (Vernam and Sutherland, 1998), hamburger is one of these kinds of food. At the beginning, chopped-meat products such as hamburgers were determined by economic factors and by the need to use low-quality meats. This factor is still important for many consumers, but it added the worldwide need to consume quality and safe food (Vernam and Sutherland, 1998).

One of the main limitations of meat and its by-products is the amount of lipids they have (Morrissey et al., 1998). This is the reason why in meat by-products it has been searched for their components, modifying their percentages of lipids and fatty acids by adding a huge variety of functional ingredients either fiber, vegetable protein, monounsaturated or polyunsaturated fatty acids, vitamins, calcium, phytochemicals, natural extracts or pulp (Restrepo, 2008). At present, importance has given to the use of natural compounds in the food industry so as to incorporate them into the making of chopped-meat (Jiménez et al., 2001).

The addition of pulps and extracts from some fruits has proved to be good to replace fat in food, aside from the addition of a higher nutritional value to chopped-meat products, such as hamburgers; however, according Restrepo (2008), in some cases these additions offer products of a lower sensorial quality and of lower physicochemical characteristics. From what has been stated above, in the de vida de la población mundial de hoy, pone en evidencia la necesidad creciente del consumo de comida rápida con un alto valor energetico y con el tiempo de preparación como un factor adicional. (Vernam y Sutherland, 1998), la hamburguesa es una de esta clase de alimentos. El inicio de productos de carne picada como las hamburguesas, fueron determinados por factores económicos y por la necesidad de usar carnes de baja calidad. No obstante, este es un factor muy importante para muchos consumidores, pero adicionalmente, el mundo necesita consumir alimentos seguros y de calidad. (Vernam y Sutherland, 1998).

Una de las pricipales limitaciones de la carne y de sus productos derivados es la cantidad de lípidos que contienen (Morrissey et al., 1998). Esta es la razón por la que en la carne y sus subproductos se ha analizado sus componentes, modificando el porcentaje de lípidos y ácidos grasos por la adición de una variedad de ingredientes fucionales, entre ellos, fibras, proteinas vegetales, ácidos grasos moniinsaturados $\mathrm{y}$ poliinsaturados, vitaminas, calcio, fitoquímicos, pulpas o extractos naturales (Restrepo, 2008). En la actualidad, se ha dado importancia al uso de compuestos naturales en la industria de alimentos, con la incorporación de estos, en la elaboración de carne picada (Jiménez et al., 2001).

La adición de pulpas y extractos de algunos frutos ha demostrado ser buena para reemplazar la grasa de los alimentos, aparte de la adición 
following study the incorporation of new raw materials to improve the quality of this product will be assessed.

A new alternative will be used in the traditional composition of hamburgers, the addition of cherry pulp and soy protein. Furthermore, the impact of the addition of cherry pulp in fat, their physicochemical 66 characteristics, their sensorial attributes and their degree of innocuousness will be assessed. To develop this scientific study the following hypothesis has been determined: the addition of cherry pulp (Prunus avium L.) to make hamburgers would reduce their fat content and would improve their chemical and sensorial attributes and their degrees of innocuousness and acceptability.

The objective of this work was analyzed physical, chemical and microbiological attributes as well as their sensorial qualities of hamburgers made with pork meet with the addition of cherry pulp and soy protein and their degrees of innocuousness and acceptability.

\section{Materials and methods}

The development of this scientific study was carried out in the laboratories of the School of Agronomy, Faculty of Agricultural and Forestry Sciences from the Catholic University of Maule located in the province of Curicó, Maule, Chile. It was carried out in the season 2014, specifically between november and march to have it coincide with the dates of harvest of the cherries used. de un mayor valor nutricional a los productos de carne picada, como las hamburguesas; sin embargo, de acuerdo con Restrepo (2008), en algunos casos esta adición, genera productos de baja calidad sensorial y de bajas características fisicoquímicas. De lo expuesto anteriormente, en el presente estudio, la incorporación de nuevos materiales para mejorar la calidad de estos productos, se evaluará.

La adición de pulpa de cereza y proteina de soya, puede ser usada como una nueva alternativa en la composición tradicional de hamburguesas. Por lo tanto, se puede valorar el impacto de la adición de pulpa de cerezas en las grasas, en 66 características fisicoquímicas, en sus atributos sensoriales y en el grado de inocuidad. Para desarrollar este estudio científico, se formuló la siguiente hipótesis: la adición de pulpa de cerezas (Prunus avium L.) para elaborar hamburguesas puede reducir el contenido de grasa y puede mejorar los atributos químicos y sensoriales, el grado de inocuidad y la aceptabilidad.

El objetivo de este trabajo fue analizar los atributos físicoquímicos y microbiológicos, así como la calidad sensorial, grado de inocuidad y aceptabilidad de hamburguesas elaboradas de carne de cerdo, con la adición de pulpa de cerezas y proteína de soya y la evaluación posterior del grado de inocuidad y aceptabilidad.

\section{Materiales y metodos}

El desarrollo de este estudio científico fue realizado en los 
Rev. Fac. Agron. (LUZ). 2021, 38: 128-150. Enero-Marzo.

Loyola et al.

\section{Vegetal materials}

The plant material worked with came from cherries (Prunus avium L.) cv. Lapins from "The Peach" orchard, belonging to Verfrut Exports, located $9 \mathrm{~km}$ away from the town called "Las Cabras" (34¹0'10.01" S Lat: $71^{\circ} 18$ '15.01" Long 0 ), on the way to Llavería, 6th region from Bernardo O'Higgins liberation fighter. The cherry plantation has 15.2 ha with a planting area of $4.5 \times 2.5 \mathrm{~m}$, planted in 2008 , lead by a central axis and drip irrigation. The thermal zone regime is characterized by average temperatures, ranging between 30.5 ${ }^{\circ} \mathrm{C}$ (maximum) and $4.5^{\circ} \mathrm{C}$ (minimum). The frost-free period is 254 days, with an average of 7 frosts per year, registering 810 cold hours annually (Santibáñez and Uribe, 1993). Water regime shows an annual average rainfall of $529 \mathrm{~mm}$, a water shortage of $1012 \mathrm{~mm}$ and a dry period of 8 months. The reduced influence of the ocean determines a significant temperature range and hot summers (Santibáñez and Uribe, 1993).

\section{Pork pulp}

Pork pulp was purchased in a certificated place for the sale of meat (butcher's at Jumbo supermarket) in Curicó, using pork pulp from meat without being preserved and which was manufactured by San Vicente Slaughterhouse Ltd., located on Highway M-66- G, km 19.2, San Vicente, O'Higgins Region, Chile. The pork pulp was purchased with about " $20 \%$ of fat", i.e., $80 \%$ of meat and $20 \%$ of fat. Once the raw material was purchased, it was kept in a freezer (Electromix brand, laboratorios de la Escuela de Agronomía, Facultad de Agricultura y Ciencias Forestales de la Universidad Católica de Maule, localizada en la provincia de Curicó, Maule, Chile. Fue realizado en el año 2014, especificamente entre noviembre y marzo, lo cual coincidió con los datos de cosecha de las cerezas usadas.

\section{Material vegetal}

El material de plantas de trabajo consistió en cerezas (Prunus avium L.) cv. Lapins, provenientes del huerto "The Peach" provenientes de Verfrut Exports, localizado a $9 \mathrm{~km}$ del pueblo llamado "Las Cabras" (34¹0'10.01 "S Lat: 71²18'15.01" Long O), en la vía de Llavería, sexta región de Bernardo O'Higgins, combatiente de la liberación. La plantación de cerezas tiene 15,2 ha, con un área de plantación de 4,5 x 2,5 m, plantadas en hileras en el 2008 y riego por goteo. El régimen térmico de la zona es caracterizado por temperaturas promedios en el rango entre $30,5{ }^{\circ} \mathrm{C}$ (máximo) y $4,5{ }^{\circ} \mathrm{C}$ (mínimo). El periodo libre de heladas es de 254 días, con un promedio de siete heladas por año, registrando 810 horas de frío anualmente (Santibáñez y Uribe, 1993). El régimen del agua muestra una precipitación promedio anual de $529 \mathrm{~mm}$, una escasez de agua de $1012 \mathrm{~mm}$ y un periodo de sequia de ocho (8) meses. La influencia reducida del oceano determina un significativo rango de temperaturas y veranos calientes (Santibáñez y Uribe, 1993).

\section{Pulpa de cerdo}

La pulpa de cerdo fue adquirida en un sitio certificado para la venta de carne (Carniceria y Supermercado Jumbo) en Curicó, usando pulpa 
Rev. Fac. Agron. (LUZ). 2021, 38: 128-150. Enero-Marzo.

Loyola et al.

model EFUP195YSKG), at $-18{ }^{\circ} \mathrm{C}$, in a laboratory from the Faculty of Agricultural Sciences of the Catholic University of Maule.

To prepare this study, the inputs used were; cherry pulp (Prunus avium L.), base for hamburgers (Tamix), pork with $20 \%$ of fat, soy protein, biosalt and water. The equipments used were: a digital $\mathrm{pH}$ meter, (brand Hanna, model HI8424), a Soxhler equipment, a refrigerant (straight), a trap, a heating blanket, a Quimis brand, (model Q-321A), an analytical balance, (Mettler Toledo brand, model AB204-S), a forced-air oven, (Binder brand, FD-115 model), a base blender, (Somela brand, Easyline BL1900 model) and plastic bags $15 \times 15 \mathrm{~cm}$.

\section{Harvest}

The cherry harvest time was determined by harvest indicators and by the maturity parameters used by the technical department of Verfrut, being dark red the color in this case, with an acidity of $0.6 \%$ and a presence of soluble solids higher or equal to $16{ }^{\circ}$ Brix, plus pulp firmness bigger than 75 Durufel units (Muñoz and Rodriguez, 2013). Once the plant material was left in the labs of the Catholic University of Maule, its disinfection was carried out with hypochlorite $5 \%$ and then frozen at $-18{ }^{\circ} \mathrm{C}$ until being used a month and a half later.

\section{Soy protein}

Soy protein was hydrated in 180 $\mathrm{mL}$ of boiling water at a 1- 3 relation, being determined with this procedure the double amount of soy protein in the components described (Acuña, 2012). Pork, cherry pulp and hydrated de cerdo de carne sin preservantes, la cual fue manufacturada por la planta de sacrificio San Vicente Ltd., localizada en la autopista M-66-G-km 19,2 San Vicente, Region O'Higgins, Chile. La pulpa de cerdo fue comprada con cerca de " $20 \%$ de grasa", esto es $80 \%$ de carne y $20 \%$ de grasa. Una vez adquirido, el material fue almacenado en un congelador (Marca Electromix, modelo EFUP195YSKG) a $-18 \quad{ }^{\circ} \mathrm{C}$ en un laboratorio de la Facultad de Agricultura y Ciencias Forestales, Universidad Católica de Maule.

Para preparar este estudio, la inversión usada fue: pulpa de cerezas (Prunus avium L.), base de hamburguesas (Tamix), cerdo con 20 $\%$ de grasa, proteina de soya, biosal y agua. Los equipos usados fueron: pHmetro digital (Marca Hanna, modelo HI8424), un extractor Soxhler, un refrigerador (convencional), una trampa, una manta de calentamiento, (Marca Quimis, modelo Q-321A), una balanza analítica, (Marca Mettler Toledo, modelo AB204-S), un horno de aire frozado (Marca Binder, modelo FD-115), un procesador (Marca Somela, Easyline modelo BL1900) y bolsas plásticas 15 x $15 \mathrm{~cm}$.

\section{Cosecha}

El tiempo de cosecha de las cerezas fue determinado por el indicador de cosecha y por los parámetros de maduración usados por el departamento técnico de Verfrut, en este caso, presencia de color rojo oscuro, acidez de 0,6\% y presencia de sólidos solubles mayor o igual a 16 ${ }^{\circ}$ Brix, pulpas con firmezas superiores a 75 unidades de Durufel (Muñoz y Rodriguez, 2013). Posteriormente, el 
Rev. Fac. Agron. (LUZ). 2021, 38: 128-150. Enero-Marzo.

Loyola et al.

ISSN 2477-9407

soy protein were separately grounded in a blender; (brand Somela Easyline, L-1900 model). Once this procedure finished, all ingredients were mixed and then they were added to the mixture; pork meet $63.4 \%$, cherry pulp $8 \%$, soy protein $4.3 \%$ and biosalt $1.1 \%$, the basis to make hamburgers until being completely homogenized. Then $120 \mathrm{~mL}$ of cold boiled water were added (pork meet 920 g. $\mathrm{mL}^{-1}$; cherry pulp 80 g. $\mathrm{mL}^{-1}$; soy protein 60 g. $\mathrm{mL}^{-1}$ and biosalt 15 g.mL $\mathrm{mL}^{-1}$ ) to it and mixed until water was fully absorbed; salt then was added and homogenized.

Once the mixture was prepared, $50 \mathrm{~g}$ hamburgers were made and wrapped in plastic bags of $15 \times 15 \mathrm{~cm}$ and then they were frozen. Differences among treatments only are related to the addition of different percentages of cherry pulp, $8 \%, 12 \%$ and $15 \%$ (figure not shown).

\section{Physicochemical analysis}

The physicochemical analysis was performed according to (AOAC, 1990).

$\mathrm{pH}: 10 \mathrm{~g}$ of hamburger with 100 $\mathrm{mL}$ of distilled water were mixed in a blender for two minutes, the resulting liquid was measured with a digital $\mathrm{pH}$ meter, (Hanna brand, HI8424 model), previously calibrated with buffers between $\mathrm{pH} 4.0$ and 7.0. Acidity: A $50 \mathrm{~mL}$ burette was used for sodium hydroxide $0.1 \mathrm{~N} .10 \mathrm{~g}$ of hamburger was taken to which 200 $\mathrm{mL}$ of distilled water were added and then liquefied for two minutes in a blender, (model Somela Easyline L-1900), $250 \mathrm{~mL}$ were filtered and measured, and then an aliquot of 25 $\mathrm{mL}$ and $250 \mathrm{~mL}$ of distilled water material fue trasladado al laboratorio de la Universidad Católica de Maule, se realizó una desinfección con hipoclorito al $5 \%$ y se almacenó en el congelador a -18 hasta ser usado un mes y medio después.

\section{Proteína de soya}

La proteina de soya fue hidratada en $180 \mathrm{~mL}$ de agua hirviendo con una relación 1:3, siendo determinado con este procedimiento una cantidad doble de proteína de soya en los componentes descritos (Acuña, 2012). El cerdo, la pulpa de cerezas y la proteína de soya hidratada fueron homogeneizadas por separado en un procesador (Marca Somela, modelo Easyline L-1900). Una vez finalizado este procedimiento, todos los ingredientes se mezclaron y entonces se fue adicionando a la mezcla: carne de cerdo $(63,4 \%)$, pulpa de cerezas (8\%), proteína de soya $(4,3 \%)$ y biosal $(1,1 \%)$, esta base para hacer las hamburguesas se homegeneizó completamente. Seguidamente, se adicionaron $120 \mathrm{~mL}$ de agua hervida fría (Carne de cerdo 920 g. $\mathrm{mL}^{-1}$; pulpa de cerezas 80 g.mL ${ }^{-1}$; protein de soya 6 g. $\mathrm{mL}^{-1}$ y biosal 15 g. $\mathrm{mL}^{-1}$ ), todo esto se mezcló, hasta que el agua fue completamente absorbida; entonces se adicionó sal y se homogeneizó totalmente.

Una vez que fue preparada la mezcla, se hicieron hamburguesas de $50 \mathrm{~g}$ y se envolvieron en bolsas plásticas de 15 x $15 \mathrm{~cm}$ y posteriormente, se congelaron. Las diferencias entre los tratamientos, solo están relacionados con los diferentes porcentajes de pulpa de cerezas ( $8 \%, 12 \%$ y $15 \%$ ) (figura no mostrada). 
Rev. Fac. Agron. (LUZ). 2021, 38: 128-150. Enero-Marzo.

Loyola et al.

ISSN 2477-9407

were put in an Erlenmeyer flask until being titrated. The result was expressed as percentage of lactic acid. Determination of fat (Soxhler): In a Soxhler equipment, raw fat was determined; it a sample was dried at $103{ }^{\circ} \mathrm{C}$, out of which $5 \mathrm{~g}$ were previously weighed and placed on heavy filter papers, and then the filter paper with the sample were put into a Soxhler rotary equipment. $100 \mathrm{~mL}$ balls were dried and weighed for a subsequent fat extraction with petroleum ether and diethyl ether for about 6 hours. After this, the final extraction of raw fat was dried and weighed, which was expressed as percentage of raw fat by weight difference (AOAC, 1990).

Moisture: It was measured in an air oven with the AOAC 950.46 method. This method is based on the gravimetric determination of the mass loss of the sample, until a constant mass is achieved in an air oven at $103^{\circ} \mathrm{C}(\mathrm{AOAC}$, 1990). A Petri dish without any sample was dried for one hour at $103{ }^{\circ} \mathrm{C}$ in an oven, (Binder brand, model FD-115), then the Petri dish without sample was cooled for 30 minutes and its weight was measured. Once the capsule was cold, a homogeneous sample of hamburger was added and again it was dried for 5 hours at $103{ }^{\circ} \mathrm{C}$ in an oven, (Binder brand, model FD-115). After five hours it was allowed to dry for 35 minutes and its weight was measured. Moisture was expressed in moisture percentage of a hamburger.

\section{Microbiological analysis}

Counting analysis were conducted in Petri plates to evaluate the presence of $E$. coli in each of the hamburgers to

\section{Análisis fiscoquímicos}

Los análisis fisicoquímicos fueron realizados de acuerdo a los métodos AOAC (AOAC, 1990).

$\mathrm{pH}: 10 \mathrm{~g}$ de hamburguesas se mezclaron con $100 \mathrm{~mL}$ de agua destilada en una licuadora durante dos minutos, en el líquido resultante fue realizada la medición con un pHmetro digital, (Marca Hanna, modelo HI8424), previamente calibrado con soluciones buffers a $\mathrm{pH}$ entre 4,0 y 7,0.

Acidez: Una bureta de $50 \mathrm{~mL}$ fue usada con hidróxido de sodio 0,1 N. 10 g de hamburguesa fue tomada, se le adicionaron $200 \mathrm{~mL}$ de agua destilada y entonces se licuó por dos minutos en un procesador, (Marca Somela, modelo Easyline L-1900), $250 \mathrm{~mL}$ fueron filtrados y medidos, seguidamente, se tomó una alícuota de $25 \mathrm{~mL}$ y fueron colocados en un matraz Erlenmeyer con $250 \mathrm{~mL}$ de agua destilada, hasta realizar la titulación. El resultado fue expresado en porcentaje de ácido láctico.

Determinación de grasa (Soxhler): La grasa cruda fue determinada en un equipo Soxhler; para ello, la muestra fue secada a $103{ }^{\circ} \mathrm{C}$, cinco (5) g fueron pesados y colocados en papel de filtro previamente pesados, y entonces el papel de filtro con la muestra fue colocado dentro del equipo giratorio Soxhler. Balones de $100 \mathrm{~mL}$ fueron secados y pesados para la subsecuente extracción de grasas con éter de petróleo y éter dietilíco por cerca de seis (6) horas. Después de esto, el extracto final de grasa cruda fue secado y pesado. El resultado fue expresado como porcentaje de grasa 
Rev. Fac. Agron. (LUZ). 2021, 38: 128-150. Enero-Marzo.

Loyola et al.

which cherry pulp was added, according to treatments $\mathrm{T}_{1}, \mathrm{~T}_{2}$ and $\mathrm{T}_{3}$. Samples were analyzed in the ANALAB Chile SA certified laboratory by the method of Petri plate count (ISO 156 16649, 2001).

\section{Sensorial analysis}

Asensorialanalysis was determined by means of an assessment made by a panel of trained people who evaluated the addition of cherry pulp at three different levels, $8 \%, 12 \%$ and $15 \%$ in treatments $\mathrm{T}_{1}, \mathrm{~T}_{2}$ and $\mathrm{T}_{3}$. A witness commercial hamburger was used with normal levels of fat and without the addition of cherry pulp. The assessment rating was first performed using unstructured primers, where the perception of sensorial attributes such as color, texture, aroma and taste were evaluated. At the same time, panelists assessed in a structured primer the levels of appearance and acceptability of the hamburgers made.

This assessment was made in the Catholic University of Maule, specifically in the laboratory of Nutritional Sciences, located in Carmen street, Curicó, coordinates $34^{\circ}$

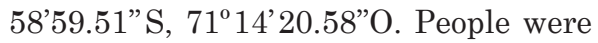
asked to mark upright with a pencil on the space, the degree of perception of the attributes texture, aroma, taste and color from a low to a high intensity. As for acceptability, they were asked to give their opinion of what they liked or disliked in each sample, according to the assessment primer; in this case, they were requested to circle one score, on a scale from 1-9, where 1 corresponded to "I extremely dislike it " and 9 corresponded to "I extremely like it " (Adapted by Stone and Sidel 1993; Adapted by Witting, 1990). cruda, por diferencia de masa. (AOAC, 1990).

Humedad: Esta fue medida en un horno de aire de acuerdo al método AOAC 950.46. Este método se basa en la determinación gravimétrica de la pérdida de masa de la muestra, hasta lograr una masa constante en un horno de aire a $103{ }^{\circ} \mathrm{C}$ (AOAC, 1990). Una capsula de Petri sin muestra fue secada por una hora a $103{ }^{\circ} \mathrm{C}$ en un horno, (Marca Binder, modelo FD-115), posteriormente, la capsula de Petri sin muestra fue enfriada por 30 minutos y fue medida su masa. Una vez que la capsula fue enfriada, una muestra homogenea de hamburguesa fue adicionada $y$ de nuevo fue secada por cinco (5) horas a $103{ }^{\circ} \mathrm{C}$ en un horno, (Marca Binder, modelo FD-115). Después de cinco horas, fue permitido el secado por 35 minutos y fue medida su masa. La humedad fue expresada como porcentaje de humedad de la hamburguesa.

\section{Análisis microbiológicos}

Análisis de conteo fueron realizados en platos de Petri para evaluar la presencia de $E$. coli en las hamburguesas a las cuales fue adicionada pulpa de cerezas, de acuerdo a los tratamientos $\mathrm{T}_{1}, \mathrm{~T}_{2} \mathrm{y}$ $\mathrm{T}_{3}$. Las muestras fueron analizadas en el laboratorio certificado ANALAB Chile SA, por el método de conteo en platos de Petri (ISO 156 16649, 2001).

\section{Análisis sensorial}

Un análisis sensorial fue determinado por medio de una valoración realizada por un panel de personas entrenado, quienes 
Rev. Fac. Agron. (LUZ). 2021, 38: 128-150. Enero-Marzo.

Loyola et al.

\section{Experimental design}

The results of the various analysis performed on hamburgers were subjected to a parametric analysis, performing a Shapirowilk and Kolmogorow-Smirornov test. Levene's test was also carried out to assess the requirements of normality and variance of the data. The treatments were: $\mathrm{T}_{0}$ : commercial hamburger (37 \% fat), $\mathrm{T}_{1}$ : hamburgers made with $63.4 \%$ of pork and $8 \%$ of cherry pulp, $\mathrm{T}_{2}$ : hamburgers made with $59.4 \%$ of pork and $12 \%$ of cherry pulp and $\mathrm{T}_{3}$ : hamburgers made with 56.4 $\%$ of pork and $15 \%$ of cherry pulp. For the comparison of the results of the physicochemical analysis and of the sensorial evaluation, a one-way analysis of variance (ANOVA) was performed, according to Tuckey test with $95 \%$ of confidence, using SPSS (v.18.0 SPCS, 2009).

\section{Results and discussion}

\section{Physico-chemical evaluations $\mathrm{pH}$}

Measurements on samples showed significant differences a mong hamburgers in the four treatments in regards to $\mathrm{pH}$ values (Figure 1). The addition of cherry pulp in $8 \%, 12$ $\%$ and $15 \%$ in $\mathrm{T}_{1}, \mathrm{~T}_{2}$ and $\mathrm{T}_{3}$ produced a significant $\mathrm{pH}$ drop, as compared to control treatment $\mathrm{T}_{0}$. This decrease was likely due to the low $\mathrm{pH}$ level cherries have and that was ratified in the analysis carried out, obtaining an average $\mathrm{pH}=3.82$, similar to $\mathrm{pH}$ values of cherries registered by Ballistreri et al. (2012). evaluaron la adición de pulpa de cerezas a tres niveles diferentes $8 \%$, $12 \%$ y $15 \%$ en los tratamientos $\mathrm{T}_{1}$, $\mathrm{T}_{2} \mathrm{y} \mathrm{T}_{3}$. Como testigo fue usada una hamburguesa comercial con niveles normales de grasa y sin la adición de pulpa de cerezas. La valoración de las categorías fue en primer lugar desarrollada usando una planilla no estructurada, donde fueron evaluadas la percepción de atributos sensoriales como color, textura, aroma y gusto. $\mathrm{Al}$ mismo tiempo, los panelistas valoraron en una planilla estructurada, el nivel de apariencia y la aceptabilidad de las hamburguesas elaboradas.

Esta evaluación fue realizada en la Universidad Católica de Maule, específicamente en el laboratorio de Ciencias Nutricionales, localizada en la calle Carmen, Curicó coordenadas $34^{\circ} 58^{\prime} 59.51^{\prime \prime} \mathrm{S}, 71^{\circ} 14^{\prime}$ 20.58"O. Se invitó a las personas a marcar responsablemente con un lápiz sobre el espacio, el grado de percepción de los atributos textura, aroma, sabor y color de menor a mayor intensidad. En cuanto a la aceptabilidad, ellos fueron invitados a dar su opinión de gusto o disgusto en cada muestra, de acuerdo a la planilla de evaluación; en este caso, la respuesta se marcó con un circulo, en una escala de 1-9, donde 1 corresponde a "Me disgusta extremadamente" y 9 corresponde a "Me gusta extremadamente "(Adaptado por Stone y Sidel 1993; Adaptado por Witting, 1990).

\section{Diseño experimental}

Los resultados de los diferentes análisis realizados a las hamburguesas fueron sometidos a 
Rev. Fac. Agron. (LUZ). 2021, 38: 128-150. Enero-Marzo.

Loyola et al.

Similar studies in sausages demonstrated that by adding natural cherry pulp with low $\mathrm{pH}$ levels to meat products resulted in even lower level of $\mathrm{pH}$ in the final product (Deda et al., 2007). Although panelists that análisis paramétricos, llevados a cabo con la prueba de Shapirowilk y Kolmogorow-Smirornov. La prueba de Levene's fue realizada para valorar los requerimientos de normalidad de la varizanza de los

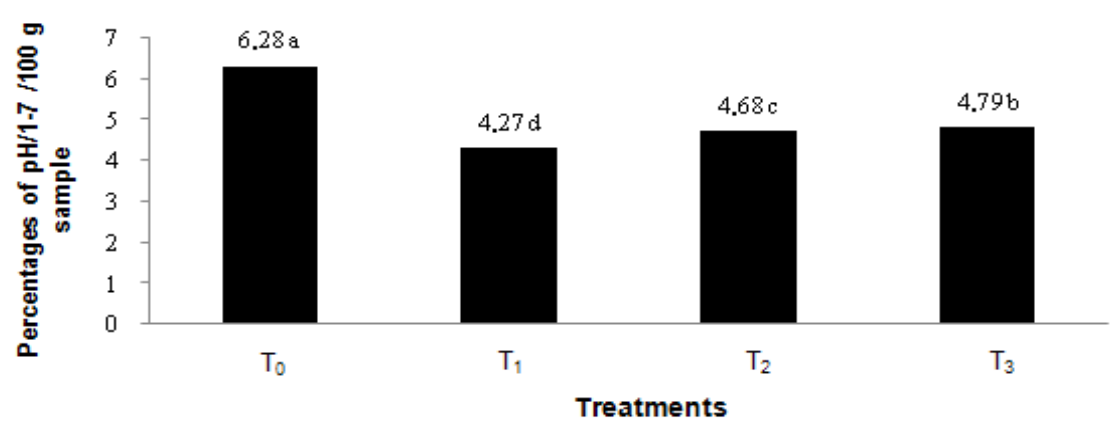

Figure 1. Average percentages of $\mathrm{pH}$, present in the different hamburgers, expressed in a $\% .100 \mathrm{~g}^{-1}$ sample. Source: Own made It.

Figura 1. Porcentajes promedio de pH, presentes en las diferentes hamburgesas, expresada en porcentaje.100 $\mathrm{g}^{-1}$ de muestra. Fuente: Elaboración propia.

assessed hamburgers in this study showed differences in their answers, they were not significantly different. In addition, panelists perceived a sour taste due to the treatments applied to make hamburgers. The $\mathrm{pH}$ values of 6.28 can have an advantage on hamburgers because foods rich in protein, having a $\mathrm{pH}$ near neutral $(\mathrm{pH}=7)$, together with high humidity percentages, would bring about the optimal conditions as a breeding ground for pathogen growth (Frazier, 1996). In contrast to what was stated by Frazier (1996), in the present study, no microbiological risk was found. datos. Los tratamientos fueron: $\mathrm{T}_{0}$ : hamburguesa comercial (37 $\%$ de grasa), $\mathrm{T}_{1}$ : hamburguesa elaborada con $63,4 \%$ de cerdo y $8 \%$ de pulpa de cerezas, $\mathrm{T}_{2}$ : hamburguesa elaborada con 59,4\% de cerdo y $12 \%$ de pulpa de cerezas y $\mathrm{T}_{3}$ : hamburguesa elaborada con $56,4 \%$ de cerdo y $15 \%$ de pulpa de cerezas. Para la comparación de los resultados de los análisis fisicoquímicos y la evaluación sensorial, se realizaron análisis de varianza (ANOVA) de una vía, de acuerdo a la prueba de Tuckey con $95 \%$ de confianza, usando SPSS (v.18.0 SPCS, 2009). 
Rev. Fac. Agron. (LUZ). 2021, 38: 128-150. Enero-Marzo.

Loyola et al.

\section{Lactic acid}

Comparatively, the percentage of lactic acid increased as compared to the control treatment of hamburgers $\mathrm{T}_{0}$, from 0.04 to 0.14 in hamburgers made in treatments $\mathrm{T}_{1}, 0.13$ in $\mathrm{T}_{2}$ and 0.11 in treatment $\mathrm{T}_{3}$ (Figure 2). According to Coma and Piquer
Resultados y discusión

\section{Evaluación fisicoquímica $\mathrm{pH}$}

En cuanto a los valores de $\mathrm{pH}$, las mediciones en las muestras mostraron diferencias significativas entre las hamburguesas en los

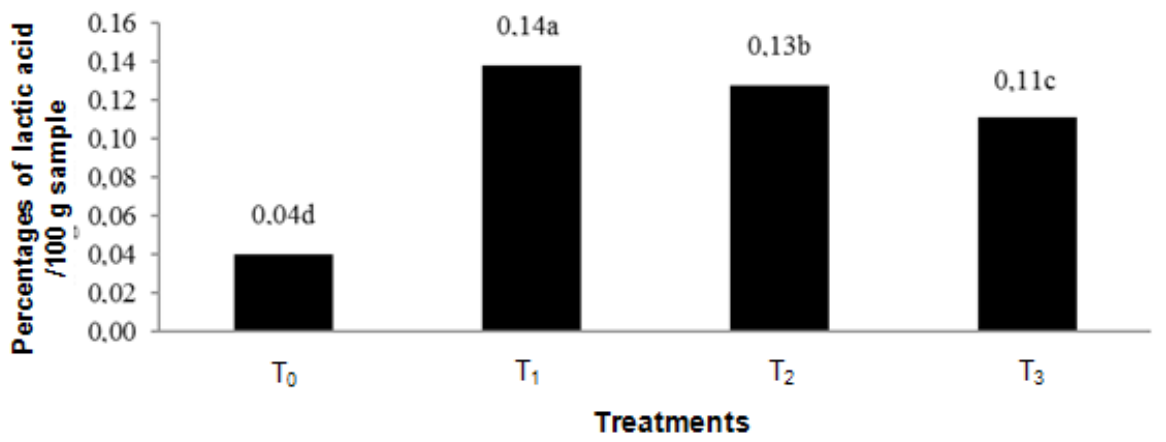

Figure 2. Average percentages of lactic acid, present in different hamburgers, expressed in a \%.100 $\mathrm{g}^{-1}$ sample. Source: Own made It.

Figura 2. Porcentajes promedio de ácido lactico, presente en las diferentes hamburguesas, expresado en porcentaje.100 $\mathrm{g}^{-1}$ de muestra. Fuente: Elaboración propia.

(1999) the high values of lactic acid, 0.14 in $\mathrm{T}_{1}, 0.13$ in $\mathrm{T}_{2}$ and 0.11 in $\mathrm{T}_{3}$ that hamburgers with the addition of cherry pulp showed in the three treatments, in regards to 0.04 in $\mathrm{T}_{0}$ without cherry pulp, would have to do with the phenomenon of glycolysis in muscle, not measured in this study; a phenomenon that consists on the transformation of glycogen into lactic acid. There is also a factor which is important in the increase of lactic acid in hamburgers, according to Deda et $a l$. (2007), it is related to the time in which the sausages and hamburgers made are stored, which would increase cuatro tratamientos (Figura 1). La adición de pulpa de cerezas en $8 \%$, $12 \%$ y $15 \%$ en $\mathrm{T}_{1}, \mathrm{~T}_{2}$ y $\mathrm{T}_{3}$, produce una significativa disminución del $\mathrm{pH}$, comparado con el tratamiento control $\mathrm{T}_{0}$. Esta disminución fue ligera debido a los bajos niveles de $\mathrm{pH}$ que tienen las cerezas y que fue ratificado en el análisis realizado, obteniéndose un promedio de $\mathrm{pH}$ de 3,82 . Similares valores de $\mathrm{pH}$ en cerezas fue registrado por Ballistreri et al. (2012).

Estudios similares en salchicha, demostraron que la adición de pulpa natural de cerezas con niveles bajos 
Rev. Fac. Agron. (LUZ). 2021, 38: 128-150. Enero-Marzo.

Loyola et al.

the elaboration of lactic acid and of other organic acids, through glycolsis in fresh tissues.

\section{Fat}

Fats are important in meat products such as hamburgers, they provide emulsion, juiciness and helps water retention and are important sources of energy (Jiménez et al., 2001; Chin et al., 2004). However, the consumption of foods with high percentages of fat is primarily responsible for heart and vascular diseases, obesity and hypertension, among others (Vural et al., 2004). This is the reason for the addition of cherry pulp to hamburgers, aimed at generating a healthy and balanced food. The values showed in Figure 3 show the difference in the percentage of fat in each treatment.

To highlight the high content of fat commercial hamburgers have, represented by $\mathrm{T}_{0}$, the differences in the content of fat in the hamburgers made in $\mathrm{T}_{1}, \mathrm{~T}_{2}$ and $\mathrm{T}_{3}$ were established, compared to treatment $\mathrm{T}_{0}$ (with 37,06\%), showing the following differences, $30.5 \%$, $33.4 \%$ and $34.4 \%$ in each case. It was observed that the average percentage of fat significantly decreased as percentages of cherry pulp and soy protein increased in each treatment; this agrees with what Izasa et al. (2012) and Cañas et al. (2011) describe, that is, the addition of the extract of cherry would decrease the content of fat in hamburgers and sausages, reducing lipid oxidation and not affecting their organoleptic properties. de $\mathrm{pH}$ a los productos cárnicos, resulta incluso en niveles bajos de $\mathrm{pH}$ en el producto final (Deda et al., 2007). Aunque en este estudio, los panelistas que valoraron las hamburguesas mostraron diferenciasensusrespuestas, ellas no fueron significativamente diferentes. Adicionalmente, los panelistas percibieron un sabor ácido debido a los tratamientos aplicados a las hamburguesas preparadas. El valor de $\mathrm{pH}$ de 6,28 puede tener una ventaja en las hamburguesas debido a que es un alimento rico en proteínas, teniendo un $\mathrm{pH}$ cercano a neutro $(\mathrm{pH}=7)$, junto con altos porcentajes de humedad, pudiera crearse un área con condiciones óptimas para el crecimiento de patógenos (Frazier, 1996). A diferencia de lo indicado por Frazier (1996), en el presente estudio, no se encontraron riesgos microbiologicos.

\section{Ácido láctico}

El porcentaje de ácido láctico se incrementó relativamente en comparación al tratamiento control de hamburguesas $\mathrm{T}_{0}$, de 0,04 a 0,14 , en las hamburguesas preparadas en los tratamientos $\mathrm{T}_{1}, 0,13$ en $\mathrm{T}_{2}$ y 0,11 en el tratmiento $\mathrm{T}_{3}$ (Figura 2).

Según Coma y Piquer (1999), los altos valores de ácido láctico, 0,14 en $\mathrm{T}_{1}, 0,13$ en $\mathrm{T}_{2}$ y 0,11 en $\mathrm{T}_{3}$, que muestran las hamburguesas con la adición de pulpa de cerezas en los tres tratamientos, con respecto a 0,004 en $\mathrm{T}_{0}$ sin pulpa de cerezas, puede ser debido al fenómeno de glicólisis en el músculo, no medido en este estudio; un fenómeno que consiste en la transformación de glicógeno en ácido láctico. En este sentido, un factor importante en el incremento 
Rev. Fac. Agron. (LUZ). 2021, 38: 128-150. Enero-Marzo.

Loyola et al.

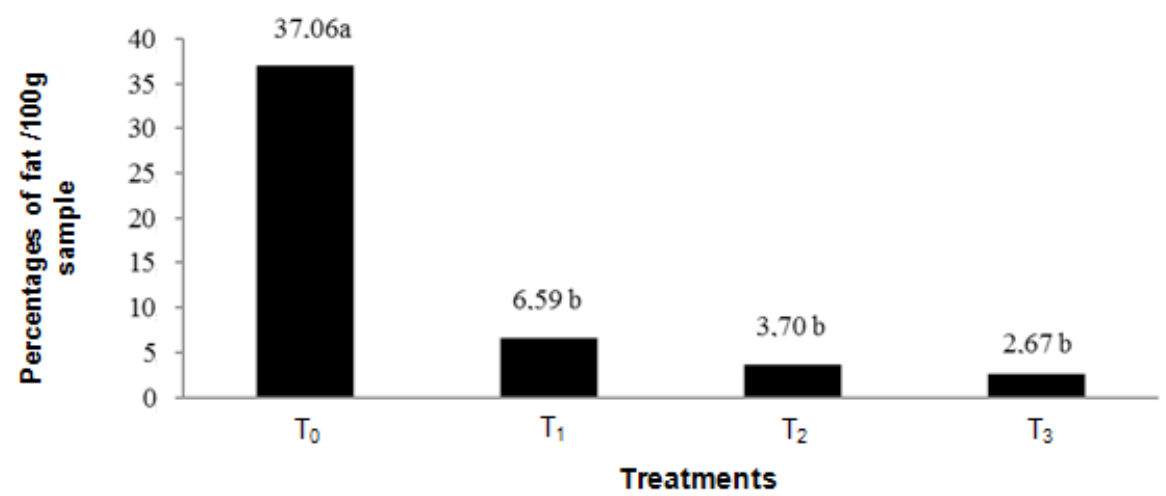

Figure 3. Average percentages of fat present in the hamburgers, expressed in a $\% .100 \mathrm{~g}^{-1}$ sample. Source: Own made It.

Figura 3. Porcentajes promedio de grasa presente en las hamburguesas, expresado en porcentaje.100 $\mathrm{g}^{-1}$ de muestra. Fuente: Elaboraion propia.

According to what Morrisey et al. (1998) said, the addition of cherry pulp decreased the amount of fat in hamburgers and improved its sensorial evaluation; it will be described below. These authors indicate that fat is mainly responsible for negative changes in organoleptic properties such as color, smell and texture.

\section{Humidity}

The results of the analysis of the samples of hamburgers with cherry pulp added showed considerable moisture values in the four treatments, but there was no significant difference among them, though hamburgers made in treatments $T_{1}$ and $T_{2}$ showed a trend to a higher content of moisture (data not shown).

The hamburgers obtained in the four treatments showed similar percentages of moisture, with an del ácido láctico en hamburguesas, de acuerdo a Deda et al. (2007), es lo relacionado al tiempo en el cual las salchichas y las hamburguesas preparadas son almacenadas, lo cual puede incrementar la producción de ácido láctico y otros ácidos orgánicos, a través de la glicólisis en el tejido fresco.

\section{Grasa}

Las grasas son importantes en productos cárnicos, como las hamburguesas, ellas proporcionan emulsión, jugos, ayudan en la retención de agua y son importantes fuentes de energía (Jiménez et al., 2001; Chin et al., 2004). Sin embargo, el consumo de alimentos con altos porcentajes de grasa, es el principal responsable de enfermedades del corazón y vasculares, obesidad e hipertensión, entre otras (Vural et al., 2004). Esta es la razón para la adición de pulpa 
average of $54.5 \%$, those made in $\mathrm{T}_{0}$ and $\mathrm{T}_{3}$ showed the lowest percentages of moisture, $50.40 \%$ and $54.37 \%$ in each case, which meant that there was a lower risk of microbiological pollution (García et al., 2006). This was corroborated by a microbiological analysis that will be described below. According to Piñero et al. (2008), in several studies with hamburgers made with low contents of fat, the importance of the amount of moisture was assessed because moisture positively affects the organoleptic properties of texture should increase, so that it increases the consumers' level of acceptability.

\section{Sensorial evaluation}

Acceptability

The sensorial evaluation of the acceptability of hamburgers did not show any significant difference, independently of the treatment applied (data not shown). Panelists had the same level of acceptance of the products made with the addition of cherry pulp $\mathrm{T}_{1}, \mathrm{~T}_{2}$ and $\mathrm{T}_{3}$, in regards to the product made without cherry pulp $\mathrm{T}_{0}$.

It could not be verified in this research what Piñero et al. (2008) pointed out and that was previously discussed here in regards to the content of moisture of hamburgers. These results are related to the measured percentage of humidity previously expressed. Panelists agreed with an evaluation of 6.4 to hamburgers in treatment $\mathrm{T}_{2}$, meaning "I like it somehow".

Hamburgers in treatment $\mathrm{T}_{1}$ were evaluated with 6.0 , corresponding to "I like it somehow". Hamburgers in treatment $\mathrm{T}_{3}$ were evaluated with 5.5, de cerezas a las hamburguesas, con el objetivo de generar un alimento saludable y balanceado. Los valores presentados en la Figura 3, muestran la diferencia en el porcentaje de grasa en cada tratamiento.

Para resaltar el alto contenido de grasa que tienen las hamburguesas comerciales, representadas por $\mathrm{T}_{0}$, las diferencias en el contenido de grasa en las hamburguesas preparadas en $\mathrm{T}_{1}, \mathrm{~T}_{2}$ y $\mathrm{T}_{3}$ fueron establecidas comparando con el tratramiento $\mathrm{T}_{0}$ (con 37,06\%), muestran las diferencias siguientes: $30,5 \%, 33,4 \%$ y $34,4 \%$, en cada caso. Se observó que el porcentaje promedio de grasa disminuye significativamente en cada tratamiento, al mismo tiempo que incrementa el porcentaje de pulpa de cerezas y la proteína de soya; esto coincide con Izasa et al. (2012) y Cañas et al. (2011), quienes describen que la adición de extractos de cerezas puede disminuir el contenido de grasa en hamburguesas y salchichas, reduciendo la oxidación de lípidos y no afectando las propiedades organolépticas.

De acuerdo a lo indicado por Morrisey et al. (1998), la adición de pulpa de cerezas disminuye la cantidad de grasas en las hamburguesas y mejora la evaluación sensorial; esto está descrito más adelante. Estos autores indican que la grasa es el responsable principal de los cambios negativos en las propiedades organolépticas, como el color, olor y textura.

\section{Humedad}

Los resultados de los análisis de las muestras de hamburguesas con la adición de pulpa de cerezas muestran valores considerables de humedad 
Rev. Fac. Agron. (LUZ). 2021, 38: 128-150. Enero-Marzo.

Loyola et al.

corresponding to "I like it somehow" and those hamburgers from treatment $\mathrm{T}_{0}$ were evaluated as "I like it somehow" with 5.6. Despite the minor differences shown in the acceptance of the assessed hamburgers, the results offered by the panelists are not significant.

\section{Organoleptic attributes}

A summary of the sensorial attributes measured on hamburgers subjected to the four treatments is shown in the Table 1. para los cuatro tratamientos, pero no tienen diferencias significativas entre ellos, a pesar de que las hamburguesas elaboradas en los tratamientos $\mathrm{T}_{1}$ y $\mathrm{T}_{2}$ muestran una tendencia a un alto contenido de humedad (datos no mostrados).

Las hamburguesas obtenidas en los cuatro tratamientos muestran porcentajes de humedad similares, con un promedio de 54,5\%, aquellas elaboradas en $\mathrm{T}_{0} \quad$ y $\quad \mathrm{T}_{3}$ muestran

\section{Table 1. Average values of organoleptic attributes assessed on hamburgers with cherry pulp.}
Cuadro 1. Valores promedio de los atributos organolépticos evaluados en hamburguesas con pulpa de cerezas.

\begin{tabular}{ccccc}
\hline Treatments & Aroma & Color & Flavor & Texture \\
\hline $\mathrm{T}_{0}$ & 7,7 & $1,4 \mathrm{~b}$ & 5,0 & $4,1 \mathrm{~b}$ \\
$\mathrm{~T}_{1}$ & 7,0 & $7,6 \mathrm{a}$ & 4,6 & $6,4 \mathrm{a}$ \\
$\mathrm{T}_{2}$ & 8,0 & $8,7 \mathrm{a}$ & 6,4 & $6,9 \mathrm{a}$ \\
$\mathrm{T}_{3}$ & 8,3 & $8,7 \mathrm{a}$ & 6,1 & $5,5 \mathrm{ab}$ \\
\hline
\end{tabular}

*The averages that are within the same column and have different letters might show statistically significant differences, according to the Tukey test $(\mathrm{p}<=0.05)$. Source: Self made.

*Los promedios que están dentro de la misma columna y tienen letras diferentes muestran diferencias estadísticamente significativas, de acuerdo a la prueba de Tukey $(p<=0,05)$. Fuente: Elaboraion propia.

\section{Aroma}

The results of the attribute aroma in the hamburgers in the four treatments expressed in (Table 1) did not show any significant difference among them $(p=0.467)$. Panelists generally rated hamburgers with a trend towards a product with a "nice aroma", according to an unstructured primer used (Stone et al., 1993). For menores porcentajes de humedad $50,40 \%$ y $54,37 \%$ en cada caso, lo cual significaba que había un menor riesgo de contaminación microbiológica (García et al., 2006). Esto fue corroborado por un análisis microbiológico que está descrito mas adelante. De acuedo con Piñero et al. (2008), en varios estudios con hamburguesas elaboradas con bajo 
panelists, hamburgers with cherry pulp added did not show major differences in the attribute aroma, making evident that panelists did not perceive any unusual scent in regards to the hamburgers in the control treatment $\mathrm{T}_{0}$. However, panelists rated hamburgers with a pleasant smell, which is a positive aspect. According to Sapiña (2013), despite of the amount of volatile aromatic components present in Prunus avium, such as alcohol and benzaldehyde, they must be in a very high concentration to be perceived. In the present study, although the aroma of the fruit was not measured, they had the same physiological maturity, measured soluble solids (16.2 ${ }^{\circ}$ Brix), thus it was assumed that they had the same aroma intensity.

In the attribute color, statistically significant differences in hamburgers with different treatments $(p=0.010)$ were observed. In hamburgers made in treatment $\mathrm{T}_{0}$, the panelists' perception and assessment was that they had a light brown color, unlike those in $\mathrm{T}_{1}$, $\mathrm{T}_{2}$ and $\mathrm{T}_{3}$, which were perceived with a dark brown color. As shown in (Table 1), hamburgers in treatments that included a higher percentage of cherry pulp were those that showed a higher tendency to dark brown, probably due to the natural process of oxidation of the fruit (Prunus avium). According to FAO (2001), meat consumption is not recommended in colors close to white. Thus, light brown in $\mathrm{T}_{0} 308$ and dark brown in $\mathrm{T}_{1}, \mathrm{~T}_{2}$ and $\mathrm{T}_{3}$ is a positive aspect.

\section{Flavor}

Judges' perception of the attribute flavor did not show significant contenido de grasa, la importancia de la cantidad de humedad fue evaluada, debido a que la humedad afecta positivamente las propiedades organolépticas de la textura, debe aumentar, de modo que aumenta el nivel de aceptabilidad de los consumidores.

\section{Evaluación sensorial Aceptabilidad}

La evaluación sensorial de la aceptabilidad de las hamburguesas, no mostraron diferencias significativas, independientemente de los tratamientos aplicados (datos no mostrados). Los panelistas tienen el mismo nivel de aceptación de los productos elaborados con la adición de pulpa de cerezas $\mathrm{T}_{1}, \mathrm{~T}_{2}$ y $\mathrm{T}_{3}$, en comparación con los productos elaborados sin pulpa de cerezas $\mathrm{T}_{0}$.

No se pudo verificar en esta investigación lo señalado por Piñero et al. (2008) y que fue dicutido anteriormente, en lo que respecta al contenido de humedad de las hamburguesas. Estos resultados están relacionados con la medición del porcentaje de humedad expresado previamente. Los panelistas coincidieron con una evaluación de 6,4 para las hamburguesas del tratamiento $\mathrm{T}_{2}$, significando "me gusta de alguna manera".

Las hamburguesas del tratamiento $\mathrm{T}_{1}$ fueron evaluadas con 6,0, correspondiento a "me gusta de alguna manera". Las hamburguesas del tratamiento $\mathrm{T}_{3}$ fueron evaluadas con 5,5 , correspondiento a "me gusta de alguna manera" y las hamburguesas del tratamiento $\mathrm{T}_{0}$ fueron evaluadas con 5,6 , correspondiento a "me gusta 
Rev. Fac. Agron. (LUZ). 2021, 38: 128-150. Enero-Marzo.

Loyola et al.

ISSN 2477-9407

differences among the hamburgers subjected to the four treatments $(\mathrm{p}=$ $0.125)$, being the average of the values of the marks between 4.6 to 6.4 , which meant that panelists perceived a homogeneous flavor, rather "salty". Those hamburgers in treatments $\mathrm{T}_{0}$ and $\mathrm{T}_{1}$ were perceived with a slight tendency towards the "salty" taste by panelists. Although there was no statistically significant difference, those hamburgers in $\mathrm{T}_{2}$ and $\mathrm{T}_{3}$ were perceived by panelists with a slight trend towards a "sweet" taste. The slight sweetness that hamburgers had in treatments $\mathrm{T}_{2}$ and $\mathrm{T}_{3}$ could be due to the amount of soluble solids cherry pulps had, according to the analysis made in the laboratory of Sciences from the Catholic University of Maule and showed average values of 16.2 ${ }^{\circ} \mathrm{Brix}$, which is associated with ranges of cherries in optimal cropping.

\section{Texture}

Panelists perceived a "loose" texture on hamburgers in treatment $\mathrm{T}_{0}$ and in a less extend those in treatment $\mathrm{T}_{3}$, while those made in treatments $\mathrm{T}_{1}$ and $\mathrm{T}_{2}$ were perceived as "crispy".

According to Grigelmo et al. (1997), meat products with high percentages of natural extracts and less fat, such as hamburgers in treatments $T_{1}$ and $\mathrm{T}_{2}$ tend to take a harder or "crunchy" texture. The texture of a food is described as the sensation its structure produces and the arrangement of its components (Vincent and Elices, 2003). Hamburgers made in treatment $T_{0}$ that had the highest content of fat and the hamburgers made in treatment $\mathrm{T}_{3}$ that had the highest percentage de alguna manera". A pesar de las mínimas diferencias mostradas en la aceptación de las hamburguesas valoradas, los resultados aportados por los panelistas no son significativos.

\section{Atributos organolépticos}

En el cuadro 1 se muestra un resumen de los atributos sensoriales medidos en las hamburguesas sometidas a los cuatro tratamientos.

\section{Aroma}

Los resultados del atributo aroma en las hamburguesas en los cuatro tratamientos mostrados en el cuadro 1 , no mostraron diferencias significativas entre ellos $(p=0,467)$. En general los panelistas valoraron las hamburguesas con una tendencia en relación con un producto con un "aroma agradable", de acuerdo a la planilla de evaluación no estructurada usada (Stone et al., 1993). Para los panelistas, las hamburguesas con pulpa de cerezas adicionadas no muestran mayores diferencias en el atributo aroma, haciendo evidente que los panelistas no perciben ningún rastro inusual en comparación con la hamburguesa del tratamiento control $\mathrm{T}_{0}$. Sin embargo, los panelistas valoraron las hamburguesas con un olor agradable, lo cual es un aspecto positivo. De acuerdo a Sapiña (2013), a pesar de la cantidad de componentes aromáticos volatiles presentes en Prunus avium, L. tales como alcoholes y benzaldehidos, ellos deben estar en una muy alta concentración para ser percibidos. En el presente estudio, aunque el aroma del fruto no fue medido, tenian la misma madurez fisiológica, indicado por la medida de los sólidos solubles (16,2 ${ }^{\circ}$ Brix), así 
Rev. Fac. Agron. (LUZ). 2021, 38: 128-150. Enero-Marzo.

Loyola et al.

ISSN 2477-9407

of pulp (Table 1) were perceived by panelists with a rather loose texture, it is explained by the lower fat content and the decreasing percentage of meat present in the components, since the characteristic texture of meat is due to the fibrous structure of muscle tissue and to the way in which fibers are separated when chewed (Vincent and Elices, 2003).

\section{Microbiological analysis}

The microbiological test was conducted to determine the presence of $E$. coli in the three treatments of hamburgers with cherry pulp $\mathrm{T}_{1}, \mathrm{~T}_{2}$ and $\mathrm{T}_{3}$. The hamburgers made in the three treatments $\mathrm{T}_{1}, \mathrm{~T}_{2}$ and $\mathrm{T}_{3}$ resulted in "it does not show anything", meaning that the unit colony forming per gram $\left(\right.$ CFU. $\mathrm{g}^{-1}$ ) was less than 10 (Ministerio de Salud, 2013), thus hamburgers are suitable for consumption because its permitted levels for consumption are 50 CFU. g ${ }^{-1}-500$ CFU. $g^{-1}$ (Ministerio de Salud, 2013).

\section{Conclusions}

The hypothesis of this study was not completely fulfilled because the addition of cherry pulp to make hamburgers effectively reduced the fat content, but the sensorial chemical aspects, acceptability and innocuousness did not show any improvement as compared to the control treatment.

Fat parameters, $\mathrm{pH}$ and acidity of the hamburgers made with cherry pulp added showed significant differences.

The sensorial attributes aroma and flavor did not show significant differences among treatments. que fue asumido que ellos tenian la misma intesidad en el aroma.

\section{Color}

En el atributo color, se observaron diferencias estadísticas $(p=0,010)$ en las hamburguesas con los diferentes tratamientos. En las hamburguesas elaboradas en el tratamiento $\mathrm{T}_{0}$, la percepción y valoración de los panelistas fue que ellas tenían un color marrón ligero, no gustandoles eso, en $\mathrm{T}_{1}, \mathrm{~T}_{2} \mathrm{y}$ $\mathrm{T}_{3}$, percibieron un color marrón oscuro. Como se muestra en el cuadro 1, las hamburguesas en los tratamientos que incluyen un alto porcentaje de pulpa de cerezas, muestran una tendencia alta a marrón oscuro, debido probablemente a los procesos de oxidación natural del fruto (Prunus avium L.). De acuerdo a la FAO (2001), no es recomendable el consumo de carne con colores cercanos al blanco, así, un marrón ligero en $\mathrm{T}_{0}$ y un marrón oscuro en $\mathrm{T}_{1}, \mathrm{~T}_{2} \mathrm{y}_{\mathrm{T}} \mathrm{T}_{3}$ es un aspecto positivo.

\section{Sabor}

La estimación de la percepción del atributo sabor no mostró diferencias significativas en las hamburguesas sometidas a los cuatro tratamientos $(p=0,125)$, siendo el promedio de los valores marcados entre 4,6 y 6,4 , en el cual las medias de los panelistas percibieron un sabor homogéneo ligeramente "salado". Los panelistas percibieron a las hamburguesas de los tratamientos $\mathrm{T}_{0} \mathrm{y} \mathrm{T}_{1}$ con una delicada tendencia hacia el gusto "salado". Aunque no se detectaron diferencias estadisticamente diferentes, las hamburguesas elaboradas en $\mathrm{T}_{2}$ y $\mathrm{T}_{3}$ fueron percibidas por los panelitas con una ligera tendencia hacia el gusto "dulce". 
Rev. Fac. Agron. (LUZ). 2021, 38: 128-150. Enero-Marzo.

Loyola et al.

There were no significant differences in the perception of color since panelists perceived as "dark" to lighter brown color.

There were significant differences regarding the attribute texture and panelists perceived as "more or less crunchy".

The hamburgers made in different treatments $\mathrm{T}_{0}, \mathrm{~T}_{1}, \mathrm{~T}_{2}$ and $\mathrm{T}_{3}$ were equally accepted by the panelists, not being shown significant differences, being expressed as "I almost like it."

Hamburgers made with cherry pulp did not show the presence of $E$. coli in any treatment.

\section{End of English Version}

El ligero endulzamiento que tienen las hamburguesas en los tratamientos $\mathrm{T}_{2} \mathrm{y} \mathrm{T}_{3}$ puede ser debida a la cantidad de solidos solubles que tiene la pulpa de cerezas, de acuerdo al análisis realizado en el laboratorio de Ciencias de la Universidad Católica de Maule y muestra valores promedios de 16,2 ${ }^{\circ}$ Brix, lo cual está asociado con el rango óptimo de cosecha de las cerezas.

\section{Textura}

Los panelistas perciben una "perdida" de textura de las hamburguesas en el tratamiento $\mathrm{T}_{0} \mathrm{y}$ la perdida se extiende al tratamiento $\mathrm{T}_{3}$, mientras que las elaboradas en los tratamientos $\mathrm{T}_{1} \mathrm{y} \mathrm{T}_{2}$ fueron percibidas como "crujientes".

Según Grigelmo et al. (1997), los productos de carne con altos porcentajes de extractos naturales, menos grasa, como las hamburguesas en los tratamientos $\mathrm{T}_{1} \mathrm{y}^{\mathrm{T}_{2}}$ tienden a tomar una textura "crujiente" o a endurecerse.

La textura de un alimento se describe como la sensación que produce la estructura y la disposición de sus componentes (Vincent y Elices, 2003). Las hamburguesas elaboradas en el tratamiento $\mathrm{T}_{0}$ que tienen un alto contenido de grasa y las hamburguesas elaboradas en el tratamiento $\mathrm{T}_{3}$ que tienen un alto porcentaje de pulpa (cuadro 1), fueron percibidas por los panelistas con una ligera perdida de textura, esto es explicado por el bajo contenido de grasa y la disminución del porcentaje de carne presente en los componentes, ya que las características de textura de la carne es debida a las estructura fibrosa del tejido muscular y a la manera en la cual las fibras son separadas cuando se mastican (Vincent y Elices, 2003).

\section{Análisis microbiológicos}

Los ensayos microbiológicos fueron realizados para determinar la presencia de $E$. coli en los tres tratamientos de hamburguesas con pulpas de cerezas $\mathrm{T}_{1}$, $\mathrm{T}_{2}$ y $\mathrm{T}_{3}$. Las hamburguesas preparadas en los tres tratamientos $\mathrm{T}_{1}, \mathrm{~T}_{2}$ y $\mathrm{T}_{3}$, resultando en "no se vé nada", indicando que las unidades de colonias formadas por gramo (CFU. $\mathrm{g}^{-1}$ ) fue menor que 10 (Ministerio de Salud, 2013), así que las hamburguesas preparadas son adecuadas para consumo, ya que los niveles permitidos para consumo son 50 CFU. g- 500 CFU. g- ${ }^{-1}$ (Ministerio de Salud, 2013).

\section{Conclusiones}

La hipótesis de este estudio no se cumplió completamente, debido 
Rev. Fac. Agron. (LUZ). 2021, 38: 128-150. Enero-Marzo.

Loyola et al.

a que la adición de pulpa de cerezas en las hamburguesas preparadas, efectivamente reduce el contenido de grasas, pero no mostró una mejora en los aspectos químicos, sensoriales, aceptabilidad e inocuidad en comparación con el tratamiento control.

Los parámetros grasas, $\mathrm{pH}$ y acidez de las hamburguesas preparadas con la adición de pulpa de cerezas, mostraron diferencias significativas.

Los atributos sensoriales aroma y sabor no mostraron diferencias significativas entre los tratamientos.

No se encontraron diferencias significativas en la percepción del color, puesto que los panelistas perciben como "oscuro" hasta ligero color marron.

No se encontraron diferencias significativas en el atributo textura y los panelistas percibieron como "más o menos crujiente".

Las hamburguesas preparadas con diferentes tratamientos $\mathrm{T}_{0}, \mathrm{~T}_{1}$, $\mathrm{T}_{2} \mathrm{y} \mathrm{T}_{3}$ fueron igualmente aceptadas por los panelistas, pero no mostraron diferencias significativas, siendo expresado como "casi me gusta".

Las hamburguesas preparadas con pulpa de cereza no mostraron presencia de $E$. coli en ninguno de los tratamientos.

\section{Literatura citada}

Acuña, C. 2012. Desarrollo de "cherryburguers" hamburguesas de cerezas y carne vacuna con reducidos niveles de colesterol y materia grasa elaboradas a partir de materia prima de bajo costo orientado a mercados de exportación. En: Informe visita ejecutivo de CORFO a planta
Chilcherry. 13 de abril. Curicó. Chilberry. p. 1-72.

Ballistreri, G., A. Continella, A. Gentile, M. Amenta, S. Fabroni, and P. Rapisarda. 2012. Fruit quality and bioactive compounds relevant to human health of sweet cherry (Prunus avium L.) cultivars grown in Italy. Food Chem 140: $630-638$.

Cañas, Z., D.A. Restrepo and M. Rodriguez. 2011. Productos vegetales como fuente de fibra dietaria en la industria de alimentos. Facultad Nacional Agrarian Medellín 64:60236035. Carrapiso, A.I. 2007. Effect of fat content on flavour release from sausages. Food chem 103:396-403. DOI:10.1016/j.foodchem.2006.07.037

Chin, K.B., H.L. Lee, S.H. Kook, and S.S. Yoo. 2004. Evaluation of various combinations of pork lean and water added on the physicochemical, textural and sensory characteristics of low fat sausages. Food science and biotechnology 13: 480-486.

Coma, J. and J. Piquer. 1999. Calidad de la carne en porcino: Efecto de la nutrición. Avances en nutrición y alimentación animal. 1-19.

Deda, M.S., J.G. Bloukas, and G.A. Fista. 2007. Effect of tomato paste and nitrite level on progressing and quality characteristics of frankfurters. Meat Science 76: 501508.

Frazier, W.C. 1996. Microbiología de los alimentos. Editorial Acribia, S.A. España. Zaragoza. 3:38-70.

García, A., P. Izquierdo, S. Uzcategui, J.F. Faria, and M. Allara, M. 2006. Formulación de salchichas con atún y carne: vida útil y aceptabilidad. FCV-LUZ. XV 3: 272-278.

Grigelmo, M.N., M.J. Motilva, and O. Martin. 1997. Characterization of low-fat Franckfurtes using peach dietary fiber as an ingredient. "Resumen". Book of abstralts, Institute of Food Technologi.sts Annual Meeting 23:15.

Jiménez, F., J. Carballo, y S. Cofrades. 2001. Heathier meat and meat products: 
Rev. Fac. Agron. (LUZ). 2021, 38: 128-150. Enero-Marzo.

Loyola et al.

The role as functional foods. Meat science 59: 5-28.

Ministerio de Salud. 2013. Dto N 977/96: Reglamento sanitario de los alimentos. Chile, Abril de 2013. 543 p.

Morrissey, P.A., P.J. Sheehy, K. Galvin, J.P. Kerry, and D.J. Buckley. 1998. Lipid stability in meat and meat product. Meat science 49: 73-86.

Muñoz, M, and S. Rodriguez. 2013. Manual cosecha de carozos. En: Reunión anual de personal. 4 de marzo. Rapel de Chile. Oficina Central planta Verfrut. p. 21-24.

Official Methods of Analysis of AOAC International. 1990. Official method of Analysis, fat and crude fiber. Association of Official Analytical Chemists, 15 edition, Arlington, USA. $780 \mathrm{p}$.

Organización de las Naciones Unidas para la Alimentación y la Agricultura, FAO - Comisión del Codex Alimentarius. 2001. Programa conjunto FAO/OMS sobre normas alimentarias. 2 y 7 junio. Ginebra Suiza. Organización mundial de la Salud. 1-301.

Organización Internacional de Normalización, ISO. 2001. ISO 16649-2:2001 Microbiology of food and animal feeding stuffs. Horizintal method for the enumeration of betaglucuronidase - positive Escherichia coli. Part 2: Colony count technique at 44 degrees $\mathrm{C}$ using 5 bromo 4 chloro 3 indolylbeta D glucuronide. Available in: https://landingpage.bsigroup. com/LandingPage/Standard? U $\mathrm{PI}=000000000030000812$. Cosulting date: abril 2004.

Piñero, M.P., M.A. Ferrer, L. Arena de Moreno, N. Huerta-Leidenz, K. Parra, and Y.M. Barboza. 2008. Effect of oat's soluble fibre (B-glucan) as a fat replacer on physical, chemical, microbiological and sensory properties of low-fat beef patties. Revista Meat Science 80:675-680. Restrepo, D.A. 2008. Reporte proyecto de investigación. Los productos cárnicos como alimentos funcionales. Universidad Nacional de Colombia, Sede Medellín.
Santibáñez, F. and J.M. Uribe. 1993. Atlas agroclimático de Chile. Regiones IV, VII,VIII y IX. Santiago de Chile. Ministerio de agricultura, fondo de investigación agropecuaria. Blanco y negro. $13 \mathrm{p}$.

Sapiña, F. 2013. Cuando es tiempo de cereza: la ciencia de la meza. Metode revista de difusión de la investigación de la Universidad de Valencia 79: 110-111.

Stone, H. and J.L. Seidel. 1993. Sensory evaluation practices. Second Edition, Academic press. N 420 y C. 53 p.

Vernam, A.H., and J.P. Sutherland 1998. Carne y productos cárnicos. Tecnología química microbiológica. Acribia, S.A. 2-13.

Vincent, J.F. and M. Elices. 2003. La textura de los alimentos: un complemento al sabor. Metode Revista de difusión de la investigación de la Universidad de Valencia 40: 112.

Vural, H.M., I. Javidipour, and O. Ozbas. 2004. Effects of interesterified vegetable oils and sugar beet fibre on the quality of frankfurters. Meat science 67: 65-82.

Witting, E. 1990. Metodología de evaluación sensorial. Facultad de ciencias químicas y farmacéuticas. Universidad de Chile. 302 p. 